\title{
Economic analysis of farmer's awareness and perception about weather based crop insurance as tool of mitigation against climate variability in north Karnataka
}

RAVI DUPDAL AND B.L. PATIL

Received : 29.04.2017; Revised : 03.08.2017; Accepted : 17.08.2017

\begin{abstract}
Protecting farming community against risks and uncertainty in agriculture, Government has launched several schemes like National Agricultural Insurance Scheme (NAIS) presently replaced by Pradhan Mantri Fasal Bima Yojana (PMFBY) during 2016 and weather index based crop insurance schemes (WBCIS). The present paper has reported the results of survey of 240 insured and non-insured sample farmers from Vijayapura and Bagalkot districts of North Karnataka which was conducted to assess the farmer's awareness and perception towards weather based crop insurance scheme. Descriptive statistical tools were employed to find out the results. Probit Model has been employed to ascertain the factors influencing on farmers awareness. From study it was clear that about $75 \%$ of farmers are aware about scheme and large holding farmers are much more aware as compare to small holding farmers in study area. Results of Probit model revealed that social participation and education level are found significant with level of awareness. The study further revealed that more than half of the insured farmers (57\%) opined that mandatory made by bank is the main reason for going insurance scheme. More than (70\%) of noninsured farmers perceived that insurance is only for large and well-off farmers. Interviewed farmers (20\%) opined that risk in agriculture could be reduced through insurance but, (30\%) of farmers perceived that government needs to provide relief funds during disaster time to safeguard the farmers from crop losses.
\end{abstract}

KEY WORDS : Risk and uncertainty, Weather based crop insurance scheme (WBCIS), Descriptive statistics, Probit model, Awareness, Perception

How to cite this paper : Dupdal, Ravi and Patil, B.L. (2017). Economic analysis of farmer's awareness and perception about weather based crop insurance as tool of mitigation against climate variability in north Karnataka. Internat. J. Com. \& Bus. Manage, 10(2) : 77-82, DOI: 10.15740/HAS/IJCBM/10.2/77-82.

\section{MEMBERS OF THE RESEARCH FORUM}

Correspondence to:

RAVI DUPDAL, Department of Agricultural Economics, College of Agriculture, University of Agricultural Sciences, DHARWAD (KARNATAKA) INDIA

E-mail: ravi.dupdal@gmail.com

Authors' affiliations:

B.L. PATIL, Department of Agricultural Economics, College of Agriculture, University of Agricultural Sciences, DHARWAD (KARNATAKA) INDIA 